Tikal Report No. 37

\title{
HISTORICAL ARCHAEOLOGY AT TIKAL, GUATEMALA
}



Tikal Report No. 37

\section{HISTORICAL ARCHAEOLOGY AT TIKAL, GUATEMALA}

Hattula Moholy-Nagy

Series Editors

William A. Haviland

Christopher Jones 
Hattula Moholy-Nagy joined the Tikal Project of the University of Pennsylvania Museum in 1960 and headed the field laboratory at Tikal from 1961 through 1964. She is currently a Consulting Scholar in the Museum's American Section.

\section{LIBRARY OF CONGRESS CATALOGING-IN-PUBLICATION DATA}

Moholy-Nagy, Hattula.

Historical archaeology at Tikal, Guatemala / Hattula Moholy-Nagy.

pages $\mathrm{cm}$. - (Tikal report; no. 37)

Includes bibliographical references and index.

ISBN 978-1-934536-47-6 (hardcover : alk. paper) - ISBN 1-934536-47-4 (hardcover : alk. paper)

1. Tikal Site (Guatemala) 2. Excavations (Archaeology) -Guatemala-Tikal Site-History. I. Title.

F1465.1.T5M65 2012

972.81 '2-dc23

2012011837

(C) 2012 by the University of Pennsylvania Museum of Archaeology and Anthropology

Philadelphia, PA

All rights reserved. Published 2012

Published for the University of Pennsylvania Museum of Archaeology and Anthropology by the University of Pennsylvania Press.

Printed in the United States of America on acid-free paper. 